$2 \frac{1}{2}=$

\title{
Experimental Study of Spark Ignition Engine Operated with Naphtha or Gasoline Blended LPG Fuel
}

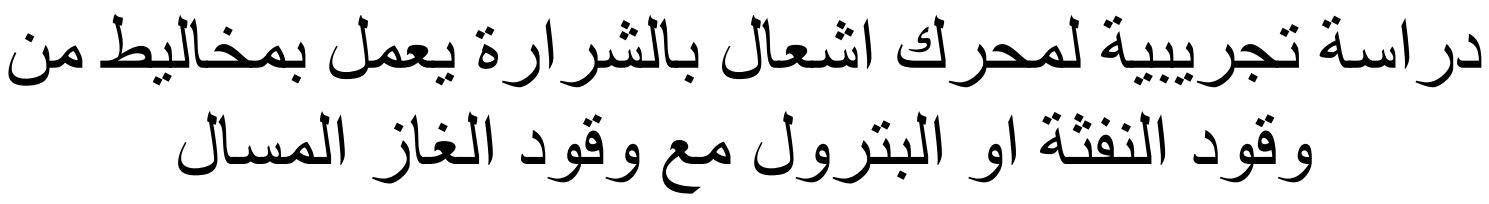

Hind A. Mohammed and Samer M. Abdulhaleem

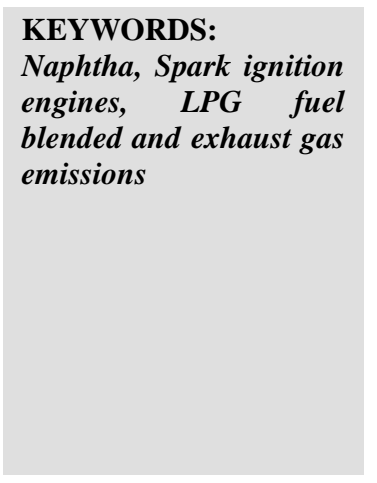

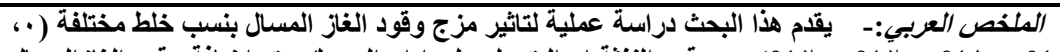

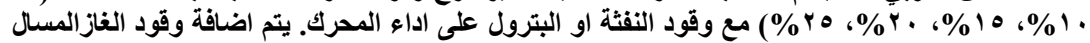

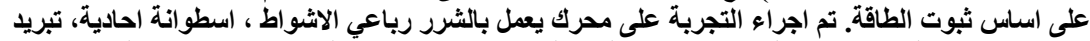

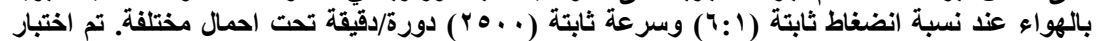

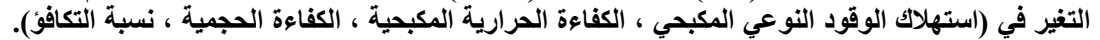

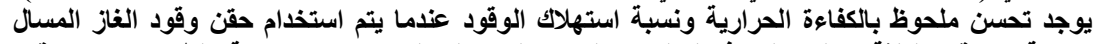

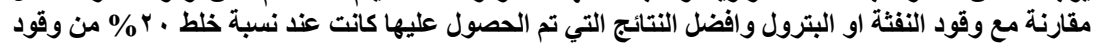

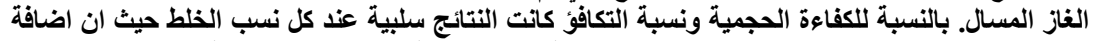

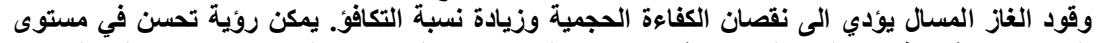

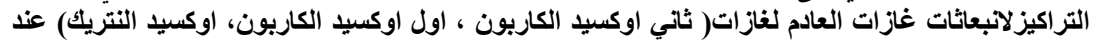

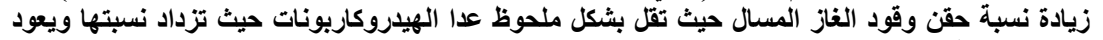
السبب لطريقة حقن الغاز المسال داخل المحرك.

\begin{abstract}
This paper presents an experimental study of the effects of LPG fuel blending in different ratio $(0,10 \%, 15 \%$, $20 \%$, and $25 \%$ ) with pure naphtha or pure gasoline on engine performance and emissions. The LPG fuel blended is done on energy replacement basis. The experiments were carried out on four stroke spark ignition engine, single cylinder and air cooled at constant compression ratio and constant engine speed of (2500) rpm under different loads. The variations in brake specific fuel consumption, brake thermal efficiency, volumetric efficiency and equivalence ratio were examined. There is a marked improvement in brake thermal efficiency and brake specific fuel consumption when LPG fuel blending was used as compared to pure naphtha or pure gasoline where best results were obtained
\end{abstract}

at using $20 \%$ LPG blending. For the volumetric efficiency and equivalence ratio the results were negative at all LPG ratio levels where addition of LPG fuel leads to a decrease in volumetric efficiency and increase in equivalence ratio. An improvement in the exhaust gas emissions concentration levels for $(\mathrm{CO}, \mathrm{CO} 2$ and NOx) with increasing in LPG fuel blending where it significantly decreases except $\mathrm{HC}$ concentration which increases due to the way of LPG injection into the engine.
Received: 15 February, 2016 - revised: 23 March, 2016 - accepted: 4 April, 2016.

Hind A. Mohammed, Iraq, Babylon, Babylon University, College of Engineering (e-mail: hialneemi@yahoo.com).

Samer M. Abdulhaleem, Iraq, Babylon, Babylon University, College of Engineering (e-mail: samir76samir76@gmail.com). 


\begin{tabular}{|l|l|c|l|}
\hline \multicolumn{2}{|l|}{ Nomenclature } & & \\
\hline bmep & brake mean effective pressure (KPa) & LPG & Liquefied Petroleum Gas \\
\hline bsfc & $\begin{array}{l}\text { brake specific fuel consumption } \\
(\mathrm{kg} / \mathrm{kW} \text {. hr) }\end{array}$ & $\mathrm{n}$ & Number of strokes (rev/cycle) \\
\hline FA & fuel - air ratio(-) & $\mathrm{N}$ & Engine speed (rpm) \\
\hline LCV & Lower calorific value $(\mathrm{kJ} / \mathrm{kg})$ & $\mathrm{P}$ & power developed $(\mathrm{kW})$ \\
\hline V & Volume $\left(\mathrm{m}^{3}\right)$ & m & Mass flow rate $(\mathrm{kg} / \mathrm{hr})$ \\
\hline Greek Symbols & & & \\
\hline$\beta$ & Blending ratio \% & $\mathrm{T}$ & Torque $(\mathrm{N} . \mathrm{m})$ \\
\hline$\Phi$ & Equivalence ratio(-) & $\eta$ & Efficiency $(\%)$ \\
\hline \multicolumn{2}{|l|}{ SUBSCRIPT } & & \\
\hline aa & air-actual & f & Fuel \\
\hline act & Actual & st & Stoichiometric \\
\hline at & theoretical air & th & Thermal \\
\hline b & brake & v & Volumetric \\
\hline D & Displacement & & \\
\hline
\end{tabular}

\section{INTRODUCTION}

$\mathrm{D}$ ue to the increasing concerns of environmental problems and high fuel prices, there was an urgent need to find an alternative fuel less expensive and environmentally friendly, so the trend has been to use Liquefied Petroleum Gas (LPG) and naphtha where both have the qualifications that make it an appropriate candidate for alternative fuel.

Liquefied petroleum gas (LPG) is product of natural gas productions and refineries, and it is widely used in commercial vehicles. LPG mainly consists of mixtures of hydrocarbons such as propane $(\mathrm{C} 3 \mathrm{H} 8)$, n-butane $(\mathrm{C} 4 \mathrm{H} 10)$ and various proportions of other hydrocarbon compounds. The high octane rating and the low carbon content and oil contamination characteristics of LPG result in a documented longer engine life time, up to twice that of the gasoline engines. LPG also has other many advantages such as high combustion value, easy storage and low cost. LPG is well known as a clean alternative fuel for vehicles because it contains less carbon molecules than gasoline which means low ratio of carbon (C) to $(\mathrm{H})$ and that reduces the amount of carbon dioxide $(\mathrm{CO} 2)$ and other non-regulated emissions compare with pure gasoline. There is a reduction in engine performance and a rise in fuel

Consumption due to the reduction in volumetric efficiency, [1]. Naphtha is a mixture of many different hydrocarbon compounds which may be derived from oil or from coal tar, and perhaps other primary sources. It is obtained in petroleum refineries as one of the intermediate products from the distillation of crude oil. It is a liquid intermediate between the light gases in the crude oil and the heavier liquid kerosene. Naphtha is volatile, flammable and has low octane number. In terms of environmental impact light steam cracked contains bio accumulative and poorly biodegradable components. The virgin naphtha is often further distilled into two streams:

1) A virgin light naphtha contains most (but not all) of the hydrocarbons with 6 or less carbon atoms.

2) A virgin heavy naphtha contains most (but not all) of the hydrocarbons with more than 6 carbon atoms. Heavy naphtha is usually processed in a catalytic reformer because the light naphtha has molecules with 6 or less carbon atoms which, when reformed, tend to crack into butane and lower molecular weight hydrocarbons which are not useful as high-octane gasoline blending components. Also, the molecules with 6 carbon atoms tend to form aromatics which are undesirable because governmental environmental regulations in a number of countries limit the amount of aromatics that gasoline may contain. It is used primarily as feedstock for producing a high octane gasoline component. Naphtha is cheap and abundant also it is used in the petrochemical industry for producing olefins in steam crackers and in the chemical industry for solvent (cleaning) applications,[2].

Knowledge of the chemical formula of the fuel used in the experiment is necessary because it is important to find equivalence ratio. Naphtha (which is produced in Annajaf city refinery) does not have constant an chemical formula so to find approach formula it was taken the average for percentages of components which gives a chemical formula C5.774H12.85. Also because the LPG fuel (which brought from Hilla gas plant) is made up of several different gases, its chemical formula can be found in a similar way as naphtha according to the percentage of each gas, so the chemical formula will be C3.624H9.248. Gasoline used in the experiment nearly is considered Iso-Octane C8H18. Some physical properties of fuels that used in the experiment are set in table (1). Various operating parameters and concerns like compression ratio, ignition timing, electronically controlled LPG injection, injection of LPG with different blends like gasoline, ethanol, methane, hydrogen and many other tested modifications been tested for better understanding of operating conditions and constrains for a LPG fueled internal combustion engine.

Choi et.al [3] investigated combustion and emissions characteristics of LPG fuelled SI engine with minor modification in the original engine to run on LPG fuel with varying volume percentage of LPG at 5\%,10\%,20\% with the help of PLC (programmable logic controller ) controller. Engine speed was maintained at $4000 \mathrm{rpm}$, the relative air-fuel ratio varies from 0.8 to 1.3 . For each proportion of LPG in gasoline investigated it was observed that the $\mathrm{CO} 2$ emissions had peaked values at around $\lambda=1$ and exhibits lower percentages at rich and lean mixtures. An increasing proportion of LPG in gasoline promotes faster burning velocity of mixture and hence reduces the combustion 
duration and subsequently the in-cylinder peak temperature increases. At high relative air-fuel ratio, the amount of NOx measured was much higher, UHC also shows remarkable reduction as the relative air-fuel ratio exceeds stoichiometric value.

Ozcan and Soylemez [4] investigated the effect of water injection on the performance of LPG fueled spark ignition engine. Different water to fuel ratios by mass was used with variable engine speed and it was concluded that the specific fuel consumption decreases while the brake thermal efficiency increases. The average increase in brake thermal efficiency for a 0.5 water to fuel mass ratio is approximately $2.7 \%$ over the use of LPG in SI engine.

Ceviz and Yuksel [5] compare the cyclic variability and emission characteristics of LPG and gasoline-fuelled spark ignition engine at lean operating conditions. Cylinder pressure, indicated mean effective pressure (imep), mass fraction burned (MFB) and combustion duration are presented in relation to cyclic variability. Variations of $\mathrm{CO}, \mathrm{CO} 2$ and $\mathrm{HC}$ emissions are also discussed. The lean operation decreases the flame speed and the burning rate, result in an increase in the overall combustion duration, However, the increase in the combustion duration when in operation with LPG is lower than that of gasoline despite working on more lean conditions. The reason for the lower combustion duration is the higher laminar burning velocity of LPG $(0.46 \mathrm{~m} / \mathrm{s})$ when compared with gasoline $(0.42 \mathrm{~m} / \mathrm{s})$ and lowered the emission.

Nawazish Mehdi and Yousufuddin [6] evaluated the performance and emission characteristics of a spark ignition engine, single cylinder, 4-stroke, air-cooled when fuelled with LPG at different compression ratios. The performance is conducted on a variable compression ratio engine using petrol and LPG at constant speeds (2500 and $2800 \mathrm{rpm}$ ), with varying loads, and at varying compression ratios of 7:1 and 10:1. Various parameters such as brake thermal efficiency, brake specific fuel consumption, volumetric efficiency, and $\mathrm{CO}$ and $\mathrm{HC}$ emissions were calculated. It was noted that as the compression ratio increases, brake thermal efficiency increases. LPG has a higher octane rating and hence the engine can run effectively at relatively high compression ratios without knock. LPG increases the specific fuel consumption of the engine. LPG reduces the engine volumetric efficiency, and thus, engine effective power. Furthermore, the decrease in volumetric efficiency also reduces the engine effective efficiency and consequently increases specific fuel consumption. The $\mathrm{CO}$ and $\mathrm{HC}$ emissions increase as the compression ratio, speed, and load increase. In the case of using LPG in spark ignition engines, the burning rate of fuel is increased, and thus, the combustion duration is decreased. Therefore, the cylinder pressures and temperatures predicted for LPG are higher compared to gasoline. The effect of variation in volumetric efficiency and engine performance at different LPG usage levels $(25 \%, 50 \%$, $75 \%$ and $100 \%$ ) on an engine equipped with electronically controlled multipoint sequential gas injection system were investigated by Gumus. [7]. The experiments were carried out at constant engine speed $(3800 \mathrm{rpm})$ and at different loads
$(5 \%, 30 \%, 60 \%$ and $90 \%)$. It is found that the volumetric efficiency decreased in proportion to LPG usage level while the engine performance showed positive results only at $25 \%$ LPG mixture ratio. Positive results were obtained at all LPG usage levels in terms of exhaust emissions. Best results were obtained at using 100\% LPG for exhaust emissions.

Zuhdi. [8] analyzed the performance of SI engine fueled with LPG which was modified to operate either on gasoline or on alternative fuel. Two different methods were adapted for operation with brake power and brake specific fuel consumption was lower compared to LPG. The results obtained indicate that with the use of injected LPG; torque, engine gasoline, while for vacuum system are higher except brake power it was found there was a decrease in power output of about $7 \%$ for LPG and reduction in BSFC was found to be $20 \%-30 \%$. On the other hand, the carbon monoxide (CO), carbon dioxide $(\mathrm{CO} 2)$ and nitrogen oxides (NOx) emissions were less in LPG mode as compared to gasoline mode while the higher hydrocarbons (HC) emissions were obtained.

Akansu and Bayrak [9] investigated the effect of LPG, hydrogen and methane mixture $(\mathrm{CH} 4 / \mathrm{H} 2)$ in the ratio of 30:70 on the four-stroke, single cylinder SI engine. Experiments were conducted at excess air ratios between 0.8 and 1.5 and at different ignition timings $\left(14^{\circ}-35^{\circ}\right.$ BTDC) under a constant load of $6 \mathrm{Nm}$ at $1400 \mathrm{rpm}$. It was concluded that NOx emission concentration was higher for $\mathrm{CH} 4 / \mathrm{H} 2$ than LPG. In case of excess air ratio less than 1.2, $\mathrm{NO}$ values were found to be low. When the ignition timing was $14^{\circ}$ and $25^{\circ} \mathrm{BTDC}$, NO values for $\mathrm{CH} 4 / \mathrm{H} 2$ was found to be lower than LPG. Concentration of $\mathrm{CO}, \mathrm{CO} 2$ and un burnt $\mathrm{HC}$ was found to be high for LPG than for $\mathrm{CH} 4 / \mathrm{H} 2$. Brake thermal efficiency was found to be higher for the $\mathrm{CH} 4 / \mathrm{H} 2$ than for LPG and it was found to be a maximum at excess air ratio of 1.15 and 1.22 for $\mathrm{CH} 4 / \mathrm{H} 2$ and LPG.

TABLE -1- PHYSICAL PROPERTIES OF TEST FUELS

\begin{tabular}{l|l|l|l}
\multicolumn{1}{c|}{ Properties } & Gasoline & \multicolumn{1}{c|}{ Naphtha } & \multicolumn{1}{c}{ LPG } \\
\hline Chemical formula & $\mathrm{C} 8 \mathrm{H} 18$ & $\mathrm{C} 5.77 \mathrm{H} 12.85$ & $\mathrm{C} 3.624 \mathrm{H} 9.248$. \\
\hline Density $(\mathrm{kg} / \mathrm{m} 3)$ & 770 & 675 & 2.137 \\
\hline $\begin{array}{l}\text { Molecular mass } \\
\text { (kg/mole) }\end{array}$ & 114.2 & 82.45 & 52.956 \\
\hline $\begin{array}{l}\text { Auto ignition } \\
\text { temperature }\left({ }^{\circ} \mathrm{C}\right)\end{array}$ & 222 & 225 & 287 \\
\hline LCV $(\mathrm{kJ} / \mathrm{kg})$ & 44100 & 44938 & 46220 \\
\hline $\begin{array}{l}\text { Research octane } \\
\text { number }\end{array}$ & 91 & 50 & - \\
\hline $\begin{array}{l}\text { boiling } \\
\text { temperature }\left({ }^{\circ} \mathrm{C}\right)\end{array}$ & 43 & 25 & -0.5 \\
\hline A/F ratio & 14.6 & 15.088 & 28.25 \\
\hline Flash point $\left({ }^{\circ} \mathrm{C}\right)$ & -43 & -21.7 & -60 \\
\hline Ignition limit & $1.4-7.6$ & $1.2-6.9$ & $1.8-8.5$ \\
\hline Properties & Gasoline & Naphtha & LPG \\
\hline Chemical formula & $\mathrm{C} 8 \mathrm{H} 18$ & $\mathrm{C} 5.77 \mathrm{H} 12.85$ & $\mathrm{C} 3.624 \mathrm{H} 9.248$. \\
\hline Density (kg/m3) & 770 & 675 & 2.137
\end{tabular}

\section{EXPERIMENTAL SET UP}

The used spark ignition engine is modified to operate with naphtha blending liquefied petroleum gas (LPG). The blending was done on energy basis and different blending ratio 
is tested. The test rig shown in Fig. (1) consists of three main units: The engine test unit, LPG injection unit and gas analysis unit. The engine test unit consists of engine test bed (TD115) Hydraulic Dynamometers, the engine (TD110), TecQuipment (TD114), and mechanical contact hand-Tachometers. Engine torque is measured directly using a hydraulic dynamometer coupled to the engine output shaft and by applying different weights with knowing the radius of the effect of weight (torque arm) [10]. Specifications of the test engine are illustrated in table (2).

TecQuipment TD114 which designed to stand beside the engine under test. In addition to the housing for the measuring devices, the unit contains the fuel tank and also an air -box / viscous flow meter which are used to damp the intake air before induction to the engine and also measuring the consumption of air by using a slant manometer to measure pressure drop and by using viscous flow meter calibration curve air flow rate can be determined. Mechanical contact hand-Tachometer instrument is used to measure the rotation speed of the engine shaft.

LPG Injection Unit consists of: LPG gas cylinder, Gas storage /regulator, Gas flow meter, and Gas mixer.

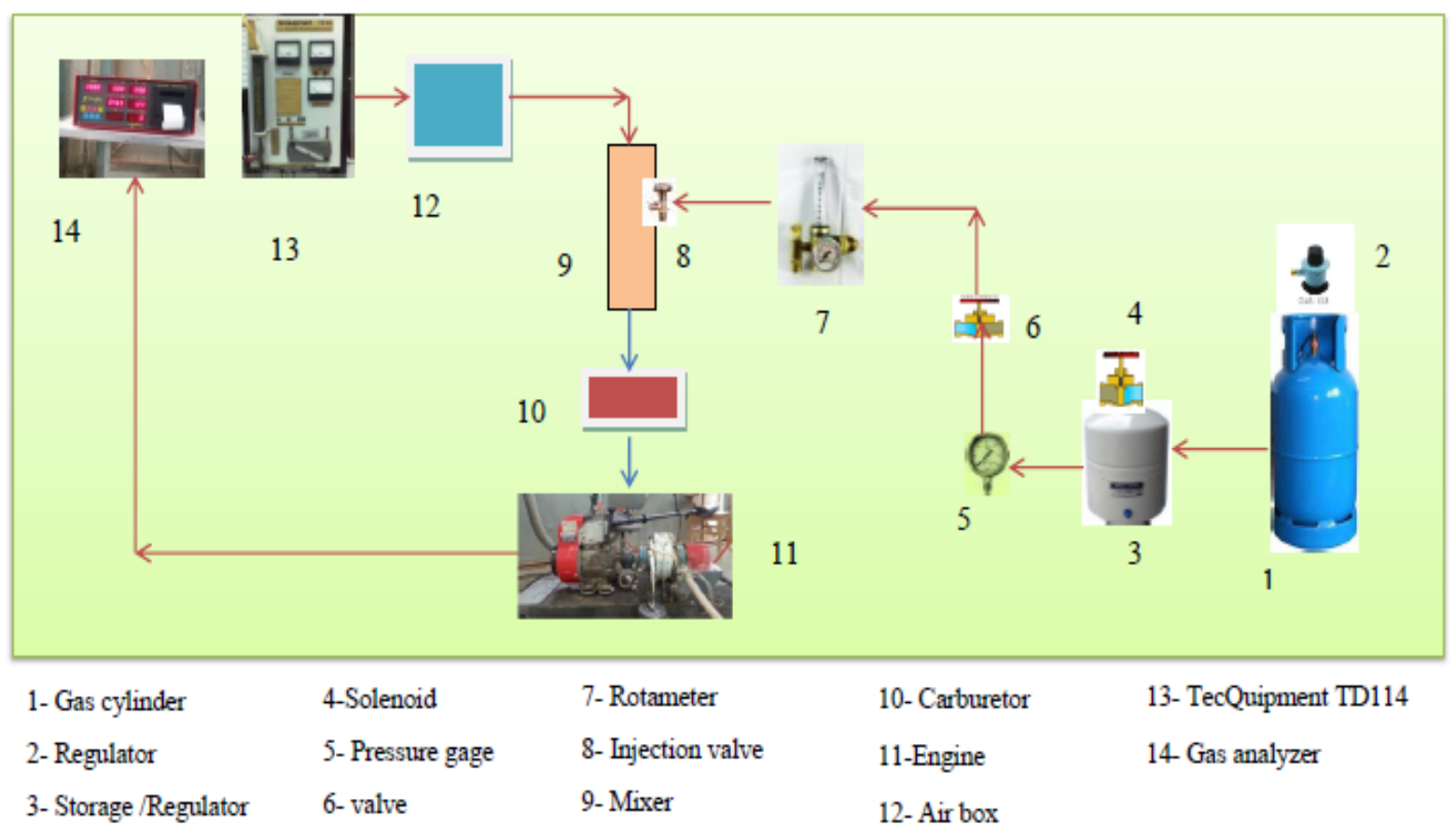

Fig.(1) Sketch of the component parts of the experimental set up

Gas storage /regulator is a cylinder of steel proved with solenoid at its upper part that controls the amount of gas enter the cylinder and in the lower part there is another solenoid provider with pressure gauge to control the gas pressure that comes out of the cylinder that not exceed 1 bar which is the pressure required to inject gas into the mixer. The purpose of this storage that is to reduce the gas pressure that equipped from the main cylinder.

Gas flow meter is a rotameter which is used essentially to measure the volume flow rate of carbon dioxide (CO2) gas was used to measure the volume flow rate of LPG after using calibrated equation.

Gas mixer is a plastic cylinder (P.V.C) provided with valve to inject gas inside the cylinder. The purpose of this mixer is to mix LPG with the air that enters the carburetor and in this way; the desired final mixture is injected into the engine. Also at the same time ensures that there is no accumulation of the mixture of LPG and air during the period that complements the engine power cycle.

Gas analysis unit: Techno test (T156/D3) exhaust gas analyzer is suitable for petrol engines. It is used to measure, display and print out the concentrations of carbon monoxide (CO), carbon dioxide (CO2), unburned hydrocarbons (HC), oxygen $(\mathrm{O} 2)$ and nitrogen oxides NOx.

\section{EXPERIMENTAL PROCEDURES}

Tests are carried out using pure naphtha (or pure gasoline) at first then it is tested with different blending ratios of LPG (from $0 \%$ to $25 \%$ ) at constant compression ratio (6:1) and constant engine speed $(2500 \mathrm{rpm})$ at various loads. In case of LPG fuel blending, the engine was started on pure naphtha(or pure gasoline) alone then the injection of LPG gradually begins and continues to increase until it is accessible to the proportion of the required injection ratio which starts from 
$0 \%$ to $25 \%$. The exhaust gas concentrations are measured using the exhaust gas analyzer type Techno test (T156/D3) to obtain the concentration of $(\mathrm{CO}, \mathrm{CO} 2, \mathrm{HC}$ and $\mathrm{NOx})$. The experimental methodology was performed as follows:

1. The engine speed was setting at speed $2500 \mathrm{rpm}$.

2. The load was varied from 0 to $12.5 \mathrm{~N}$. m every $2.5 \mathrm{~N} . \mathrm{m}$.

3. After engine reached thermal equilibrium the exhaust gas temperature was recorded using TecQuipment (TD114).

4. Using a stopwatch, time for fuel consumption during a certain volume $(8 \mathrm{ml})$ was recorded for each load.

5. The exhaust gas analyzer is warmed up almost for 20 minutes, and then the concentrations of $\mathrm{CO}, \mathrm{CO} 2, \mathrm{HC}$ and NOx are recorded.

6. The above all procedures were repeated for anther LPG blending ratio.

TABLE (2) SPECIFICATIONS OF THE TEST ENGINE

\begin{tabular}{l|l}
\multicolumn{1}{c|}{ Type } & \multicolumn{1}{c}{ Spark ignition, four stroke } \\
\hline Manufacture & Tecumseh products company \\
\hline Cycle & Otto \\
\hline Bore & $54.34 \mathrm{~mm}$ \\
\hline Stroke & $63.5 \mathrm{~mm}$ \\
\hline Capacity & $195 \mathrm{cc}$ \\
\hline Compression ratio & $6: 1$ \\
\hline Max. Power output & $7.5 \mathrm{~kW}$ \\
\hline Max. Torque & $15 \mathrm{~N} . \mathrm{m}$ \\
\hline Cooling type & Forced air cooled \\
\hline Max. Speed & $3750 \mathrm{rpm}$
\end{tabular}

\section{CALCULATIONS AND MATHEMATICAL FORMULAE}

After the engine reaches thermal equilibrium, the required data are recorded such as engine speed, slant manometer reading, fuel consumption duration, load applied on the engine in $\mathrm{kg}$, then the emission parameter such as $\mathrm{CO}, \mathrm{CO} 2, \mathrm{HC}$ and NOx are recorded. While engine performance like torque, brake power, fuel consumption, brake specific fuel consumption, brake thermal efficiency, brake means effective pressure, volumetric efficiency and equivalence ratio are calculated. The torque is determined by the following relation: [10].

The brake power developed is calculated from the relation:

$p_{b}=\frac{2 \pi \mathrm{NT}}{60}$

Thermal efficiency can be determined as follows:

$\mathrm{\eta}_{t h}=\frac{\mathbf{P}_{\mathbf{b}}}{\dot{\mathrm{m}}_{\mathrm{f}}(\mathbf{L C V})_{\mathrm{f}}} \times 100 \%$

In case of fuel LPG blending:

$\dot{\mathrm{m}}_{f} \times \mathrm{LCV}_{f}=\left(\dot{\mathrm{m}}_{L F} \times \mathrm{LCV}_{L F}\right)+\left(\dot{\mathrm{m}}_{\mathrm{LPG}} \times \mathrm{LCV}_{\mathrm{LPG}}\right)$

LCV of LPG is calculated as follows:

LCVLPG $=\sum \mathrm{Xi}(\mathrm{LCV}) \mathrm{i}$
The brake specific fuel consumption which represents how much the engine is efficient to produce work from the fuel supplied; it is calculated using the relation:

$\frac{\dot{\mathrm{m}}_{\mathbf{f}}}{\mathbf{P}_{\mathbf{b}}} b s f c=\dot{\mathrm{m}}_{-} f / \mathrm{P}_{-} \mathrm{b}$

In case of fuel LPG blending:

$\dot{\mathrm{m}} f=\dot{\mathrm{m}} L F+\dot{\mathrm{m}} L P G$

Brake mean effective pressure is obtained from the following formula:

bmep $=\frac{60 \mathrm{n} \mathbf{P}_{\mathbf{b}}}{2 \mathbf{N ~}_{\mathbf{d}}}$

Volumetric efficiency is the ratio between the amount of air that actually enters the cylinder and the amount of air that could enter under ideal standard atmospheric conditions.

$\mathrm{y} \boldsymbol{v}=\frac{\dot{\mathrm{m}}_{\mathrm{aa}}}{\dot{\mathrm{m}}_{\mathrm{at}}} \times 100 \%$

The blending ratio for LPG is defined as follows:

$\beta L P G=\frac{\dot{\mathrm{m}}_{\mathbf{L P G}} \times \mathbf{L C V}_{\mathbf{L P G}}}{\dot{\mathrm{m}}_{\mathbf{L F}} \times \mathbf{L C V}_{\mathbf{L F}}} \times 100 \%$

Equivalence ratio $(\Phi)$ is a measure of the fuel-air mixture relative to stoichiometric conditions and calculated from the relations:

$\phi=\frac{\mathbf{F A}_{\text {act }}}{\mathbf{F A}_{\mathbf{s t}}}$

\section{RESULTS AND DISCUSSION}

To demonstrate the validity of the experimental results a comparison is performed between the results of the present work which it was obtained at $3500 \mathrm{rpm}$ and compression ratio 6:1 at energy replacement basis for pure gasoline and $25 \%$ LPG blending ratio and the result made by Gumus. [7] work which results were obtained at $3800 \mathrm{rpm}$ and compression ratio 9:1 with volume replacement basis for pure gasoline and (75\% gasoline $+25 \%$ LPG). Figures (2), (3) and (4) show the comparison of engine performance represented for brake specific fuel consumption, brake thermal efficiency and volumetric efficiency respectively and it can be seen good agreement in trend, but the levels of bsfc and thermal efficiency for the present work are higher than for the ref.[7] work, while volumetric efficiency for the ref.[7] work higher than the present work. Acceptable agreement in behavior appear in figures (5) and (6) which show the comparison of engine exhaust gas emissions for carbon monoxide concentration and carbon dioxide concentration respectively. The results of $\mathrm{CO} 2$ concentration for the present work has less value than for the ref.[7] work and the results of $\mathrm{CO}$ concentration for the present work is higher than for the ref.[7] work due to injection of LPG fuel in the air manifold before

LCVi: Lower calorific value of LPG components. 


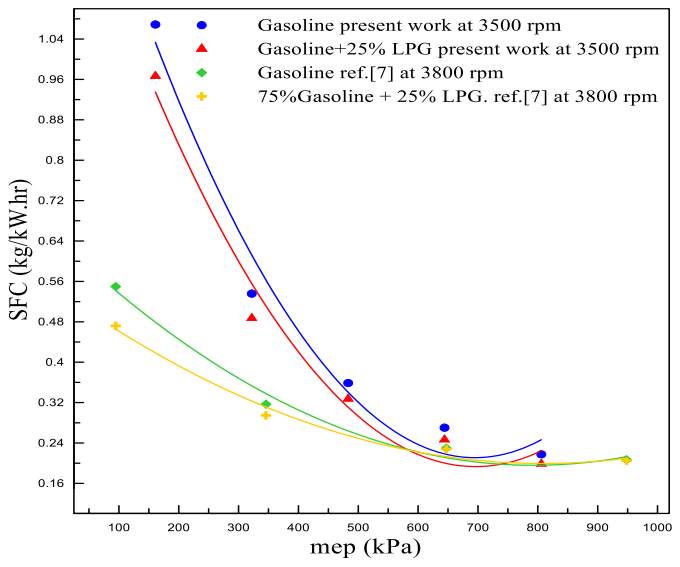

Fig.(2) Comparison of specific fuel consumption results obtained in the present work with results of ref.[7]

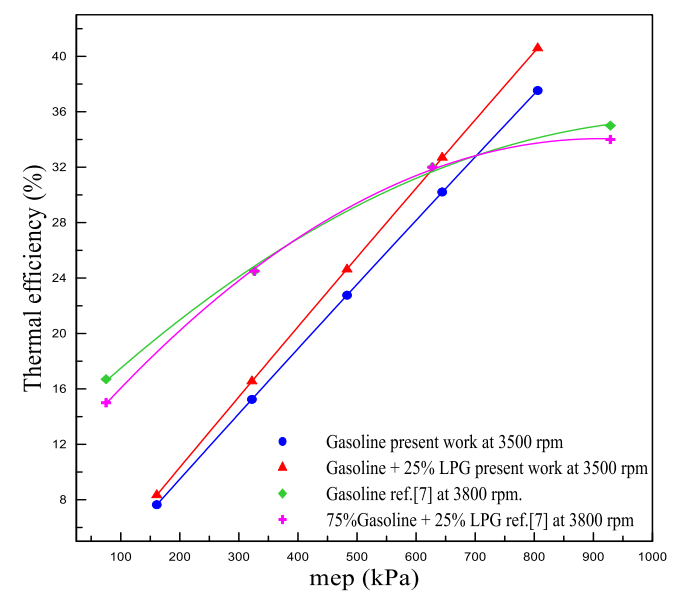

Fig.(3) Comparison of thermal efficiency results obtained in the present work with results of ref.[7]

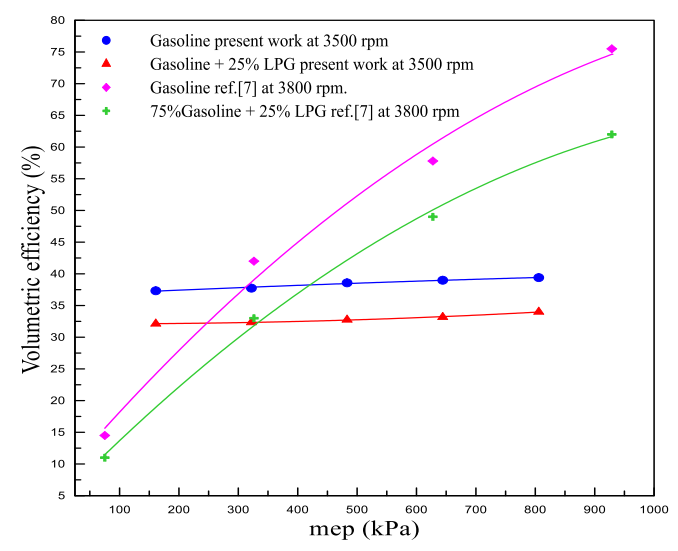

Fig.(4) comparison of volumetric efficiency results obtained in the present work with the results of ref.[7]

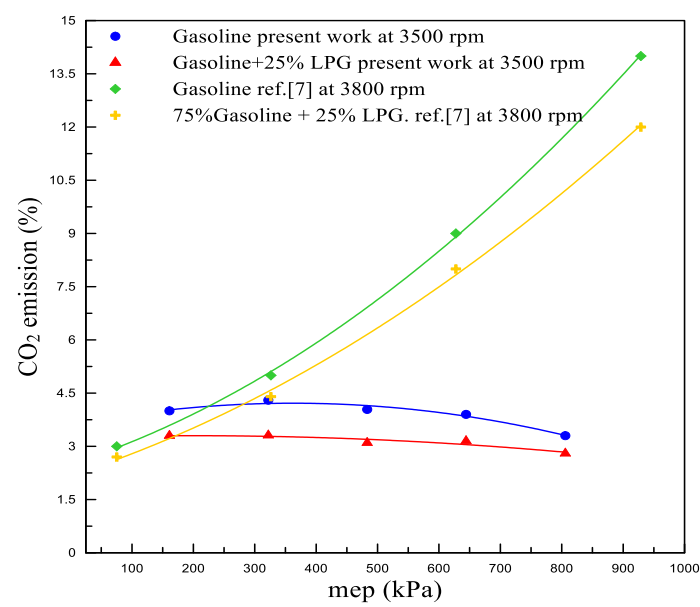

Fig.(5) comparison of $\mathrm{CO} 2$ emission results obtained in the present work with results of ref.[7]

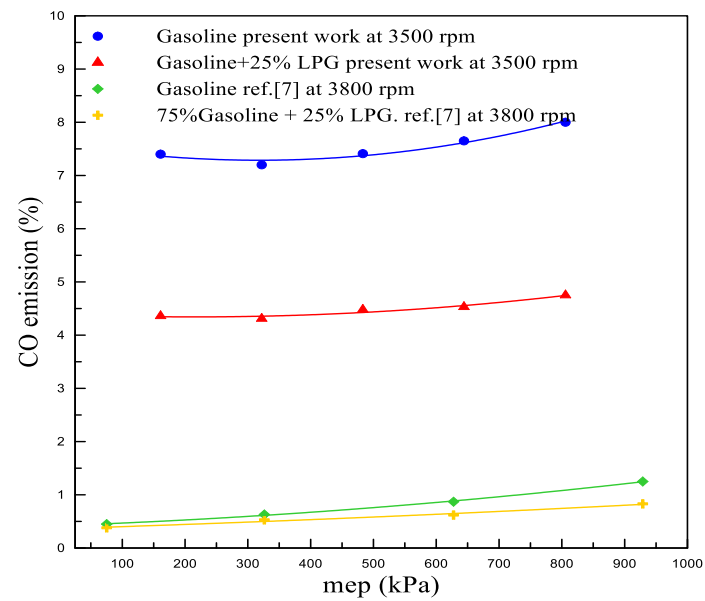

Fig.(6) comparison of $\mathrm{CO}$ emission results obtained in the present work with results of ref.[7]

Figures (7 and 8) show variation of brake specific fuel consumption and brake thermal efficiency with respect to the LPG blending ratio for naphtha fuel and gasoline fuel under loads of $(2.5,5,7.5$ and 12.5) N.m respectively. A clear improvement in bsfc and brake thermal efficiency can be noted with addition of LPG fuel and best results was obtained at $20 \%$ LPG blending. LPG blending improves the combustion process through the enhance of flame speed due to its high octane number and the high volatility of the gaseous fuel, therefore less time required for the completion of the combustion process which increases of the pressure and the temperature of the cylinder gases and decrease the heat transfer compared with pure naphtha or pure gasoline. The increase in the ratio of LPG blending more than $20 \%$ led to reduction of thermal efficiency as a result of reduction in volumetric efficiency.

Figure (9) shows variation of volumetric efficiency with respect to the LPG blending ratio for naphtha fuel and gasoline fuel under loads $(0,5,7.5$ and 12.5) N.m respectively. A negative behavior appear with LPG fuel blending due to gaseous state and low density of LPG fuel which makes it occupying large volume compared to liquid fuel and that causes in reduction of volumetric efficiency. 
Figure (10) shows variation of equivalence ratio with respect to the LPG blending ratio for naphtha fuel and gasoline fuel under loads of $(0,5,7.5$ and 12.5) N.m respectively. In general equivalence ratio tend to increase with LPG blending except at $15 \%$ naphtha-LPG blending and $10 \%$ gasoline-LPG blending where it have been decrease. This increase due to the fact that the gas injection was before the carburetor in the air stream which reduces the amount of air entering the cylinder and thus volumetric efficiency decreases and mixture gets richer.

Figures (11and12) show a reduction in carbon dioxide $(\mathrm{CO} 2)$ and carbon monoxide $(\mathrm{CO})$ concentration respectively with LPG fuel blended at different ratio $(0-25 \%)$ under loads of $(0,5,7.5$ and 12.5) N.m. That is due to the lower carbon to hydrogen ratio in LPG fuel compared with pure gasoline or pure naphtha. The decrease in carbon dioxide concentration are more significant at percentage 10\% of gasoline-LPG blending ratio and $15 \%$ of naphtha-LPG blending ratio.

Figure (13) shows decrease of nitrogen oxides concentration (NOx) as increase in increasing in LPG blending ratio. An increasing proportion of LPG in naphtha or gasoline enhances burning velocity of mixture which reduces the combustion duration and subsequently the in-cylinder peak temperature increases. So when high temperature and high oxygen concentration are available the formation of NOx increase , but due to the way of LPG fuel injection which reduce the volumetric efficiency and eliminate the air flow therefore the cylinder combustion temperature reduce which reduces the formation of NOx.

Figure (14) shows increase in unburned hydrocarbons (HC) concentration as LPG blending ratio increase because LPG blending increase the richness of the mixture which reduce the amount of air required to complete the combustion Therefore, emissions due to unburned $\mathrm{HC}$ are increased.

Figure (15) shows decrease of exhaust gas temperature as addition of LPG fuel due to reduction in volumetric efficiency which lead to un complete combustion and reduced cylinder gas temperature.

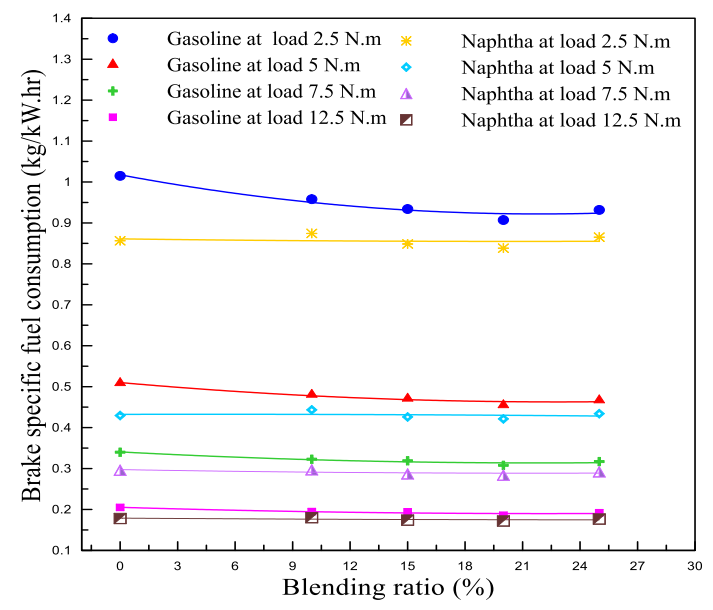

Fig. 7 Effect of LPG blending ratio on bsfc at different load for gasoline \& naphtha fuels

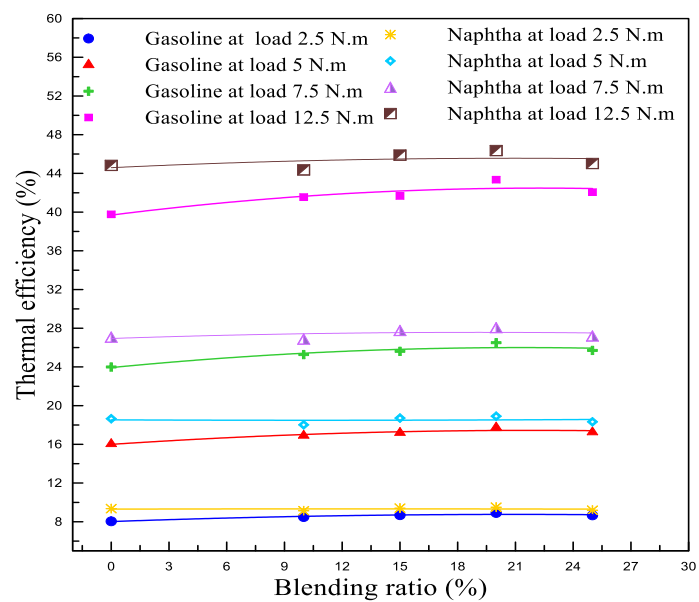

Fig. 8 Effect of LPG blending ratio on break thermal efficiency at different load for gasoline \& naphtha fuels

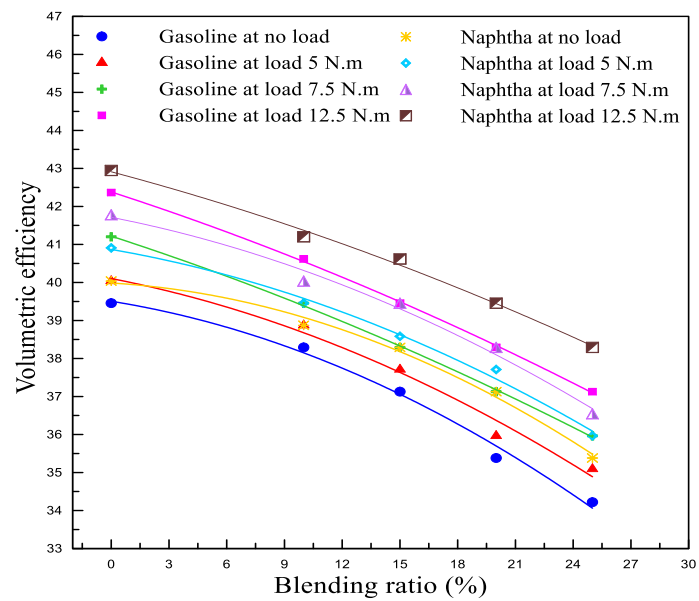

Fig. 9 Effect of LPG blending ratio on volumetric efficiency at different load for gasoline \& naphtha fuels

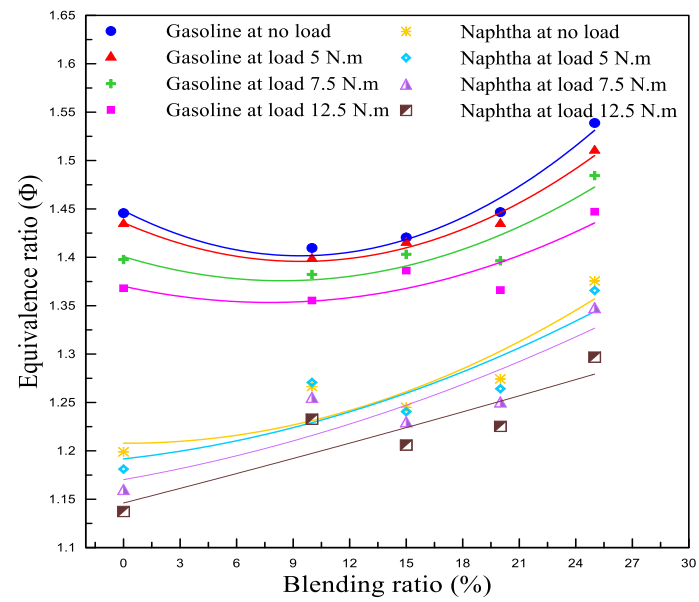

Fig. 10 Effect of LPG blending ratio on equivalence ratio at different load for gasoline \& naphtha fuels 


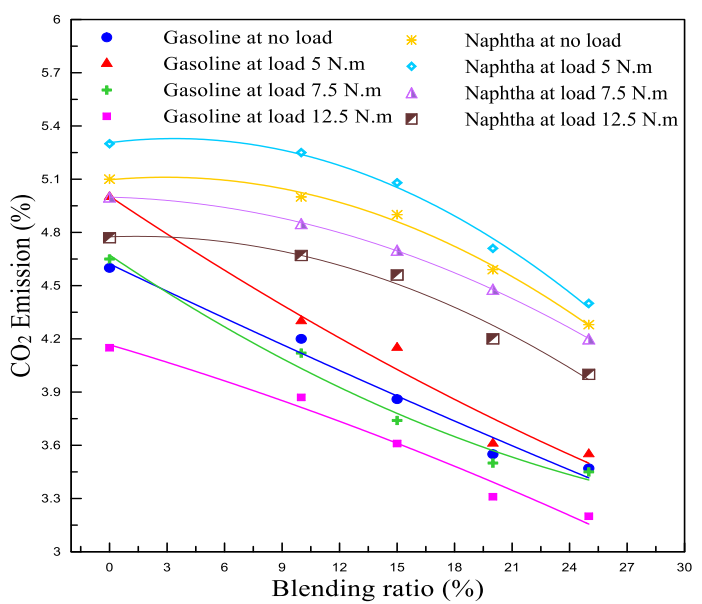

Fig. 11 Effect of LPG blending ratio on $\mathrm{CO} 2$ emission at different load for gasoline \& naphtha fuels

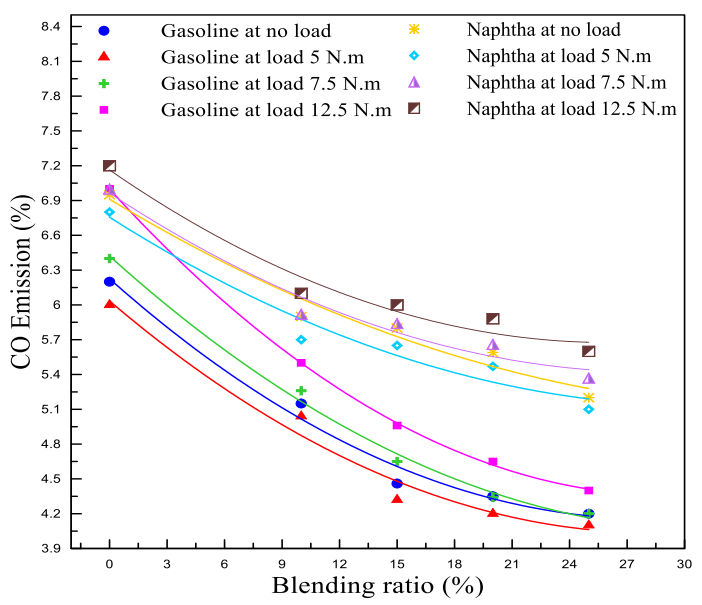

Fig. 12 Effect of LPG blending ratio on CO emission at different load for gasoline \& naphtha fuels

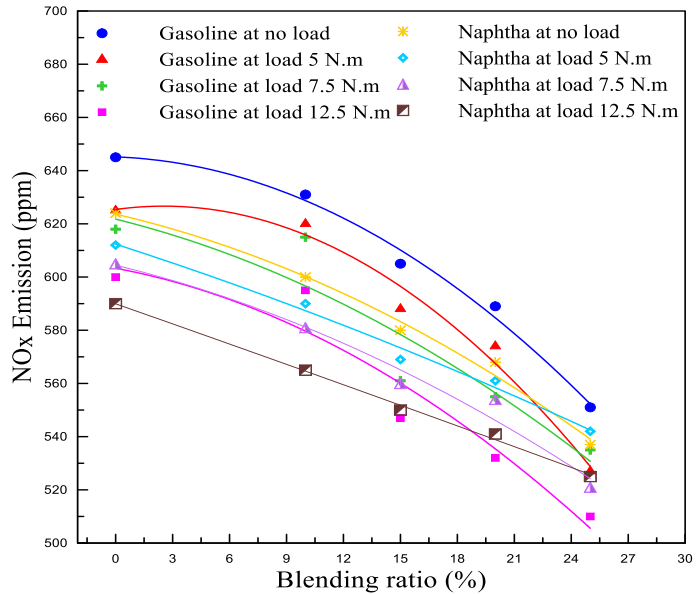

Fig. 13 Effect of LPG blending ratio on NOx emission at different load for gasoline \& naphtha fuels

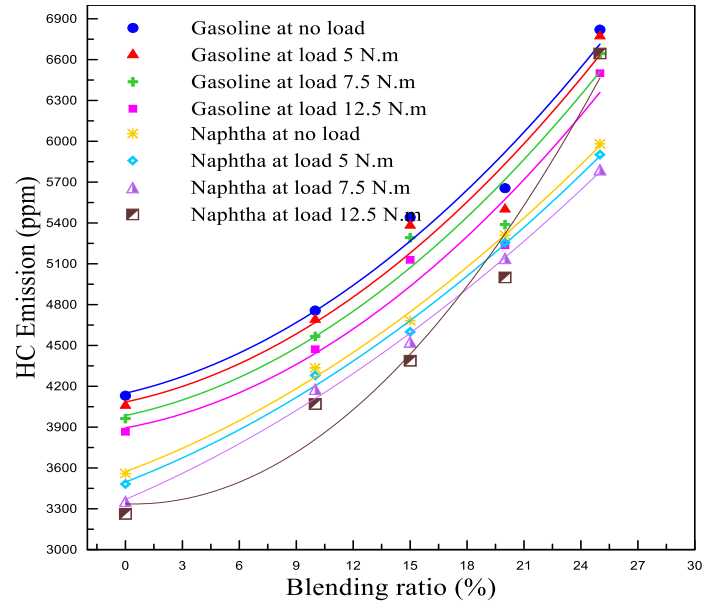

Fig. 14 Effect of LPG blending ratio on HC emission at different load for gasoline \& naphtha fuels

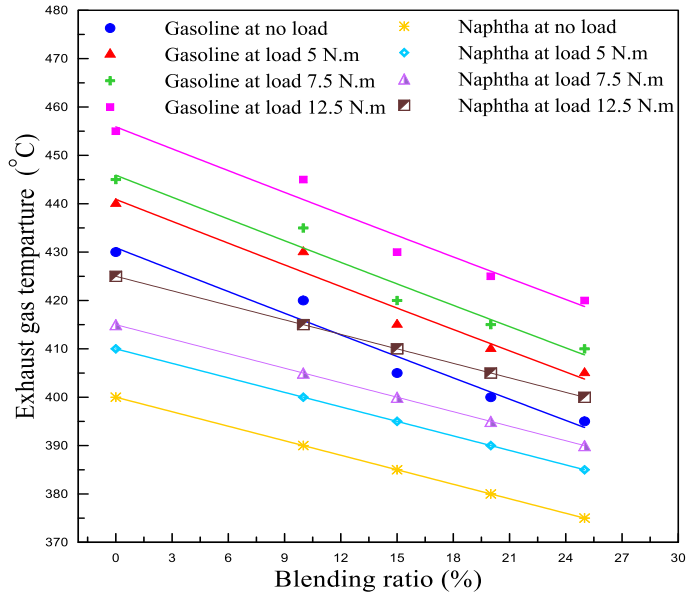

Fig. 15 Effect of LPG blending ratio on exhaust gas temperature at different loads for gasoline \& naphtha

\section{CONCLuSions}

Based on the obtained results the following conclusions can be drawn:

1. The LPG fuel can be used as a combustion promoter with low octane liquid fuel such as naphtha to improve its combustion process and the Naphtha could be used as engine fuel.

2. LPG fuel blending improves engine efficiency and gives maximum reduction in specific fuel consumption at a blending ratio about $20 \%$.

3. A reduction in volumetric efficiency occurs due LPG fuel blended.

4. Addition of LPG fuel decreases the exhaust gas emissions concentrations for $(\mathrm{CO} 2, \mathrm{CO}, \mathrm{NOx})$ and increase $\mathrm{HC}$ concentrations.

5. LPG fuel blending increases the richness of the mixture; therefore it's appropriate with lean mixture. 


\section{REFERENCES}

[1] Kalra, Dheeraj, A. Veeresh Babu, and M. Vijay Kumar., "Effects of LPG on the Performance and Emission Characteristics of SI Engine-An Overview." International Journal of Engineering Development and Research, Vol. 2, No. 3, Sept 2014.

[2] Chemistry of Hazardous Materials, p.p.458, Third Edition”, Meyer, E., Prentice Hall, 1998.

[3] Choi, G. H., J. H. Kim, and Christian Homeyer. "Effects of different LPG fuel systems on performances of variable compression ratio single cylinder engine.", ASME 2002 Internal Combustion Engine Division Fall Technical Conference. American Society of Mechanical Engineers, 2002.

[4] Özcan, Hakan, and M. S. Söylemez., "Thermal balance of a LPG fuelled, four stroke SI engine with water addition." Energy conversion and management, Vol.47, No.5, pp. 570-581, 2006.

[5] Ceviz, M. A., and F. Yüksel., "Cyclic variations on LPG and gasolinefuelled lean burn SI engine." Renewable Energy, Vol. 31, No.12, pp. 1950-1960, 2006
[6] Yousufuddin Syed, and Syed Nawazish Mehdi., "Performance and emission characteristics of LPG-fuelled variable compression ratio SI engine.” Turkish J. Eng. Env. Sci., Vol. 32, pp. 7-12, 2008.

[7] Gumus. M., "Effects of volumetric efficiency on the performance and emissions characteristics of a dual fueled (gasoline and LPG) spark ignition engine." Fuel Processing Technology, Vol. 92, No.10, pp. 18621867, 2011.

[8] Salhab Zuhdi, etal., "Comparative performance and emission properties of spark-ignition outboard engine powered by gasoline and LPG.", Jordan Journal of Mechanical and Industrial Engineering, Vol. 5, No. 1, pp. 47 52, 2011.

[9] Akansu, Selahaddin Orhan, and Mehmet Bayrak., "Experimental study on a spark ignition engine fueled by $\mathrm{CH} 4 / \mathrm{H} 2$ (70/30) and LPG.", international journal of hydrogen energy, Vol. 36, No.15, pp. 9260-9266, 2011.

[10]"Performance Characteristics of an internal combustion engineMechanical Engineering Systems Laboratory". ME410 Labsheet. Exp. 4 March 2015. 